\title{
Software Development of Word Search Game on Smart Phones in English Vocabulary Learning
}

\author{
Anon Sukstrienwong \\ School of Science and Technology \\ Bangkok University \\ Rama IV road, Klong-Toey, Bangkok, 10110, Thailand \\ anon.su@bu.ac.th
}

\author{
Patravadee Vongsumedh \\ School of Science and Technology \\ Bangkok University \\ Rama IV road, Klong-Toey, Bangkok, 10110, Thailand \\ patravadee.v@bu.ac.th
}

Received: May 20, 2019. Revised: September 12, 2021. Accepted: October 5, 2021. Published: November $22,2021$.

\begin{abstract}
At present, mobile devices are a medium of learning in school that is enjoyable with educational content. They are becoming as a part of daily life with new software games, which are considered as entertainment. As we all know, a word search game has been implemented on mobile devices for decades. It facilitates English vocabulary acquisition of students. The word search game on mobile devices allows education to be delivered in a more flexible way, anytime and anywhere at the students' own place. To this paper, a survey is conducted to target Thai students at Bangkok University, Thailand. Therefore the word search game on smart phones embedded with the English dictionary, which helps Thai students to memorize the words is developed. Additionally, the process in developing the word search game on smart phones has been presented. It is expected that our research findings in English learning on mobile devices for Thai students will be further shared in the future.
\end{abstract}

Keywords-Educational software; English learning; mobile game; mobile application; word search game

\section{INTRODUCTION}

Student's English learning involves memorization of a large number of vocabulary words and grammatical structures. New technology devices such as smart phones, personal digital assistants (PDAs), tablet computers, iPhones, and other mobile devices are invented to help in English learning. Nevertheless, these devices are often disguised as a game device because they are highly capable of playing a variety of games. However, there exist evidences that games improve student's understanding and the learning outcomes [1]. Mobile devices, therefore, impact educational outcomes and facilitate new learning which is learner-center, situated, collaborative, ubiquitous, and lifelong [2]. Currently several games have proven to be beneficial for academic achievement because games can mainly be integrated within a classroom to improve student learning and participation [3], [4], [5]. Games involve the basic language skills such as listening, speaking, reading, and writing [6]. Game-based learning on mobile has being proposed for undergraduate research [7], [8], [9]. Some traditional teachings in classes can be replaced by games. Teachers can use the games' metaphors and illustrations of reading and Math exercises [10], [11]. Therefore, utilization of mobile phones as a medium of learning in school has increased [12], [13]. In the work of Saran and friends [14], this work focuses on phones in language learning. The results indicate that students' abilities to learn Irish autonomously in the pilot project were enhanced by the use of mobile phones. Students were remarked on progress made in grammar and vocabulary. They were delighted to use the instructional materials in their mobile phones in language learning. SMS may be one of the most common wireless applications used with mobile wireless phones to support teaching [15]. Another interesting work published by Thornton and Houser shows that graduate students in Japan often use their mobile devices such as smart phones and PDAs for daily sending and receiving e-mail [16]. The paper emphasizes on providing English vocabulary by three mini-lessons to students each day. Even the biggest group of students ( 57 percent of students) read messages once a day. However, the researchers had demonstrated that SMS helps improve student scores in classes. In addition, several mobile games have been designed for students to learn English. Word search game is one of the excellent games that are good for players to spend free time memorizing vocabulary and to enhance problem-solving skills. This type of game is an example of activity that takes a great deal of time to prepare by hand, but very little to do on the computer [17].

Word search game is known as a word find game, which is well known for helping students to recognize words. It is a game that letters of a word lay in a grid and usually has a square shape. To play this game, players search and mark all hidden words inside the grid. In the most word search games, a list of hidden words is provided. Frequently, many words are related which are easy for players to search for. Listed words may be arranged in horizontal, vertical or diagonal directions in the grid. Sooner you complete every level, higher score you will get. In searching for words, users read and memorize the words while they are playing the game that helps them learn the words and spelling, letter by letter, in the puzzle.

Unlike other word search games, in this paper we aim to develop the word search game on smart phones for Thai students in English vocabulary learning. Also, we want to understand the needs of Thai students on this kind of games. However, we want to develop a word search game for smart phones as educational media because they are wildly used among teenagers. We do not want to propose using artificial intelligence $(\mathrm{AI})$ techniques to develop the application. The major design is based on our user-needs survey. There are four sections to our paper including this introduction. The brief overview of word search game is shown in Section 2. Section 3 presents the design of our word search game in details. The user-needs survey is described to support our system design and development. The usability of evaluation in developing the 
word search game and the evaluation of satisfaction is provided in this section. Finally, conclusion and discussion are prepared in the last section.

\section{THE DESIGN OF WORD SEARCH GAME}

Our word search game is designed to play on smart phones to help students recognize English vocabulary words. Adapted from user interaction model called star life cycle of Hartson and Hix [18], only four areas of interest are identified as follows; application design, task design, physical design of interface and usability evaluation as shown in Fig. 1. This life cycle presents an evaluation-center approach; we can start developing the program at any point of the cycle while these activities are interconnected through evaluation in the center [19]. In the following part, we detail briefly on an "informal description" of the design phases.

\section{A. Application Design Phase}

In traditional classes, students are considered as the recipients, which affect both the teachers' instructional approaches and learning strategies [20], therefore we have to get to know the needs of our students. In common, the first phase in our application development process is the application analysis. It covers the user analysis, as a better understanding of concerned users which will lead to design the best to meet users' needs. We are concerned that the users have control over the functioning of the system. The quickest way of finding out the users' needs is to question some representative members of the desired group. We conduct a survey to explore the needs of the students about the word search game in learning English. The survey results give important information and several facts as shown in Table 1. Students prefer the program with a special feature allowing them to create their word search lists associated to their topics, while some players concern for the quality of the graphical interface of the program. Additionally, the mobile devices such as smart phones are the device that students are likely to choose to play the word search game (54.7\%), which is higher than newspaper (29.3\%). Moreover, a feature that most players prefer to have within the word search

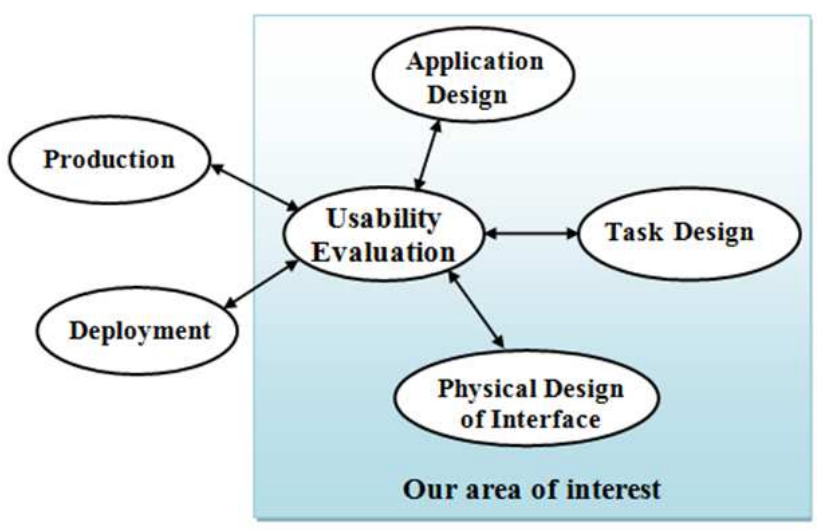

Fig. 1. Star life cycle and our area of interest is dictionary (94.1\%). Nevertheless, if the word search game is too difficult, they will immediately stop playing the word search game $(57.7 \%)$.

TABLE I. SURVEY RESULTS OF USER'S NEEDS

\begin{tabular}{|c|c|c|}
\hline No. & Questions & Scores and Results \\
\hline 1 & $\begin{array}{l}\text { Have you ever played the word } \\
\text { search game? }\end{array}$ & $\begin{array}{l}\text { Yes }(100 \%) \\
\text { No }(0 \%)\end{array}$ \\
\hline 2 & $\begin{array}{l}\text { Is it good to enhance your English } \\
\text { by playing the word search? }\end{array}$ & Avg. score 4.13 out of 5 \\
\hline 3 & $\begin{array}{l}\text { Is there any application out there } \\
\text { that allows you to play word } \\
\text { search? }\end{array}$ & $\begin{array}{l}\text { No }(71 \%) \\
\text { Yes }(29 \%)\end{array}$ \\
\hline 4 & $\begin{array}{l}\text { Have you ever wished that you } \\
\text { could create your own word in } \\
\text { word search? }\end{array}$ & $\begin{array}{l}\text { Yes }(100 \%) \\
\text { No }(0 \%)\end{array}$ \\
\hline 5 & $\begin{array}{l}\text { If you do not have internet } \\
\text { provided, which media or device } \\
\text { would be good for you to play } \\
\text { word search? }\end{array}$ & $\begin{array}{l}\text { Smart phones }(54.7 \%) \\
\text { Newspaper }(29.3 \%) \\
\text { Others }(15.9 \%)\end{array}$ \\
\hline 6 & $\begin{array}{l}\text { What feature or program should be } \\
\text { within the word search game to } \\
\text { enhance your English? }\end{array}$ & $\begin{array}{l}\text { Dictionary }(94.1 \%) \\
\text { WordPad }(2.3 \%) \\
\text { Others }(3.5 \%)\end{array}$ \\
\hline 7 & $\begin{array}{l}\text { Is there any reason that will make } \\
\text { you not to play the word search } \\
\text { game? }\end{array}$ & $\begin{array}{l}\text { Too difficult }(57.8 \%) \\
\text { Word list not related to } \\
\text { player }(31.6 \%) \\
\text { User interface }(8.1 \%) \\
\text { Other reasons }(2.4 \%)\end{array}$ \\
\hline
\end{tabular}

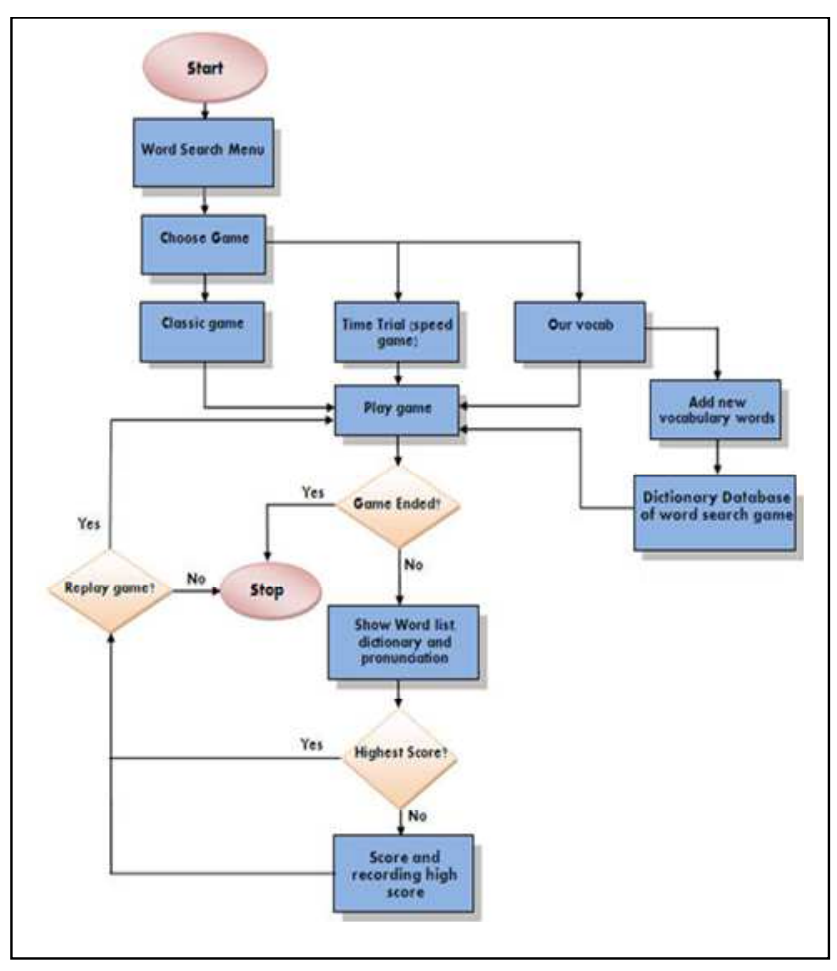

Fig. 2. Task analysis 


\section{B. Task Design}

Task analysis is a fundamental methodology to define our module in developing word search game. Procedures are determined sequentially so that each step is unambiguous and simple as shown in Fig. 2. The game is divided to three options; classical game, time trial (speed game), and our vocab. In the last option of the game, it allows users to add new vocabulary words to the word search game.

\section{Physical Design of Interface}

Our word search game is designed for Thai students in Bangkok University in English vocabulary learning. The chosen development environment is Java 2 Micro Edition (J2ME) on iPhone OS. Xcode is integrated for creating our game on smart phones as well. It includes the Xcode IDE, Instruments, iOS Simulator. To this game, the players have three options to select, which are classic mode, time trial, and our vocab or self-adjusting modeas represented in Fig. 3.

\section{a) Classic mode}

This mode is a common word search game. The players can select the level of difficulty of the game; easy, normal and hard; as shown in Fig. 4(a). The screen will automatically display English characters in the $9 \times 9$ characters table for players to search for hidden words. The list of random vocabulary words is shown at the end of the table; see Fig. 4(b). If the players have found any words in the grid, the players mark a box covering that word. When all existing words are discovered, the game shows the meanings of each word including pronunciation for players to listen. However, the players can click on a hint button for help when they cannot search the words. Finally, the scores of each game are calculated based on how many words are found.

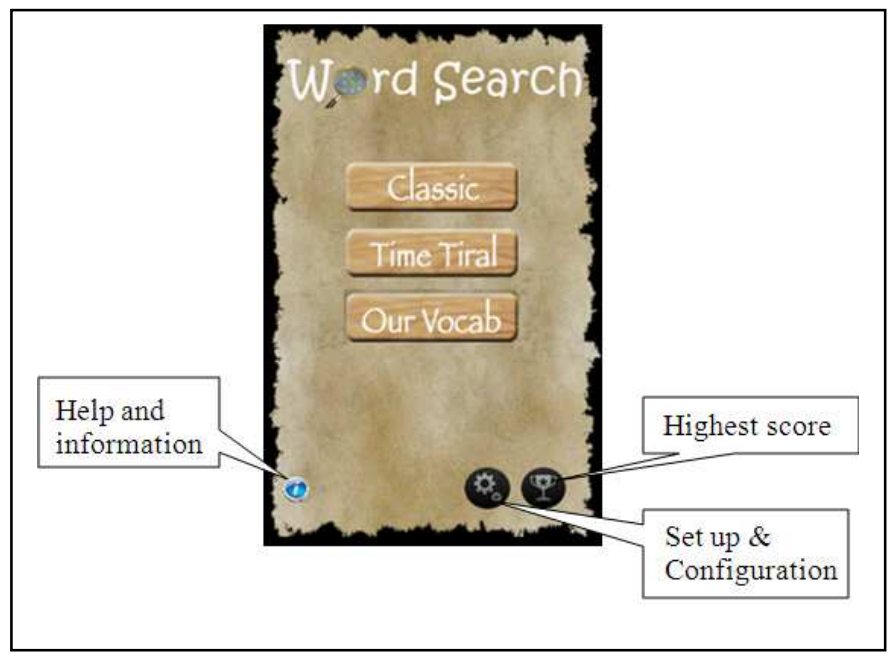

Fig. 3. Main menu of word search game

\section{b) Time trial mode:}

This mode is designed to stimulate the users to play with timing. The game's countdown timer starts from 180 to zero seconds. If the time becomes zero, the current game automatically stops. This challenges most of students to play with fun. At the end of each game, vocabulary words will be summarized with their meaning and proper pronunciation. In addition, this part provides the hint button in the cases that uses cannot search the word hidden in the table. To click this hint button, the players will lose the points. The highest scores can be recorded in the system if the users want.

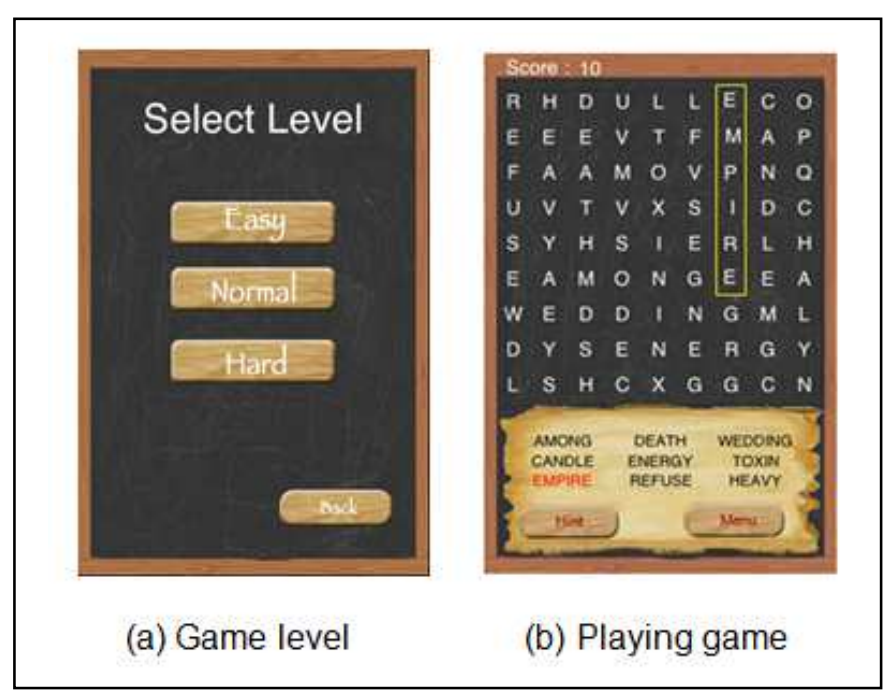

Fig. 4. Word search game (Classic mode)

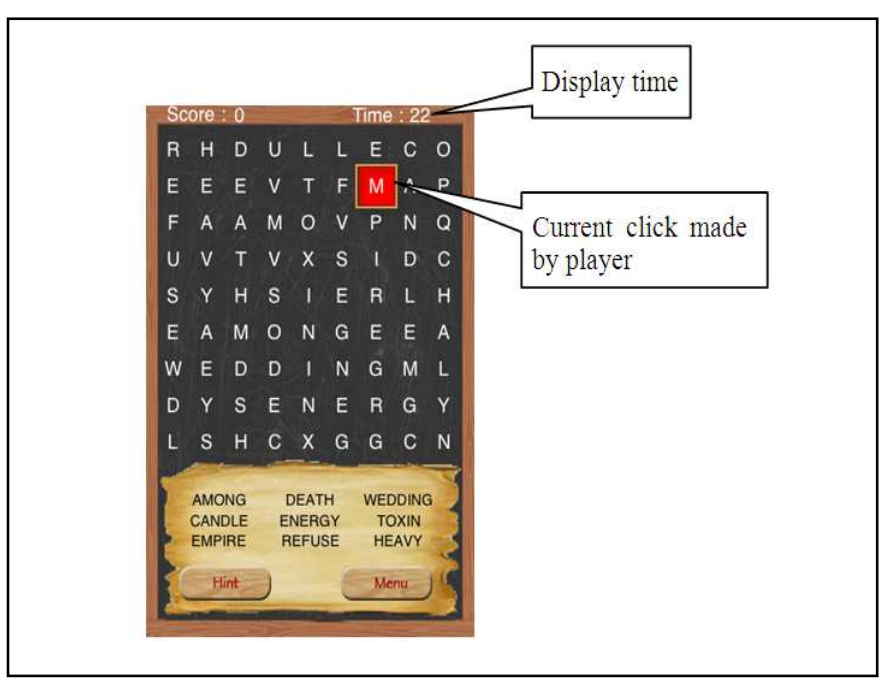

Fig. 5. Game interface (Time trial mode)

\section{c) Our vocab mode}

This mode is customizable and more flexible than other modes because new vocabulary of any topics can be added into the game. The system allows the players to add new topics related to the players which are easy for them to search for. As it can be seen in Fig. 6, "Emotion" is a new topic that is arbitrarily set by a user. This mode facilitates the students to enter new words into their own database helping them to practice later. However, with the limitation of game the pronunciation of the new word added words cannot be recorded to the system. 
At the end of each game, the system automatically shows total score and bonus rewarded during the play. In addition, a list of random words of the game is displayed sequentially with their meanings and pronunciation, see Fig. 7.

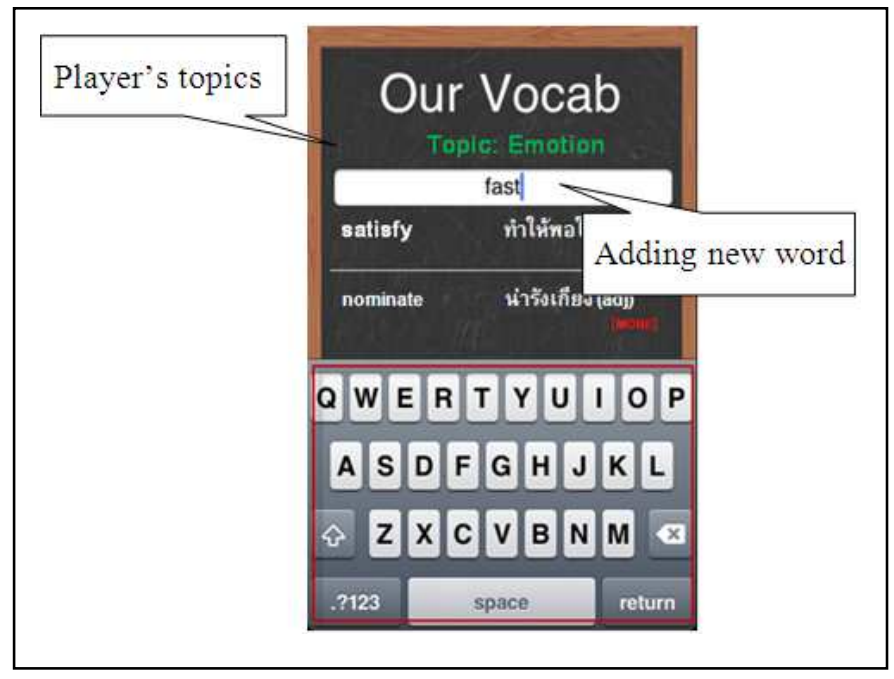

Fig. 6. Game interface (Time trial mode)

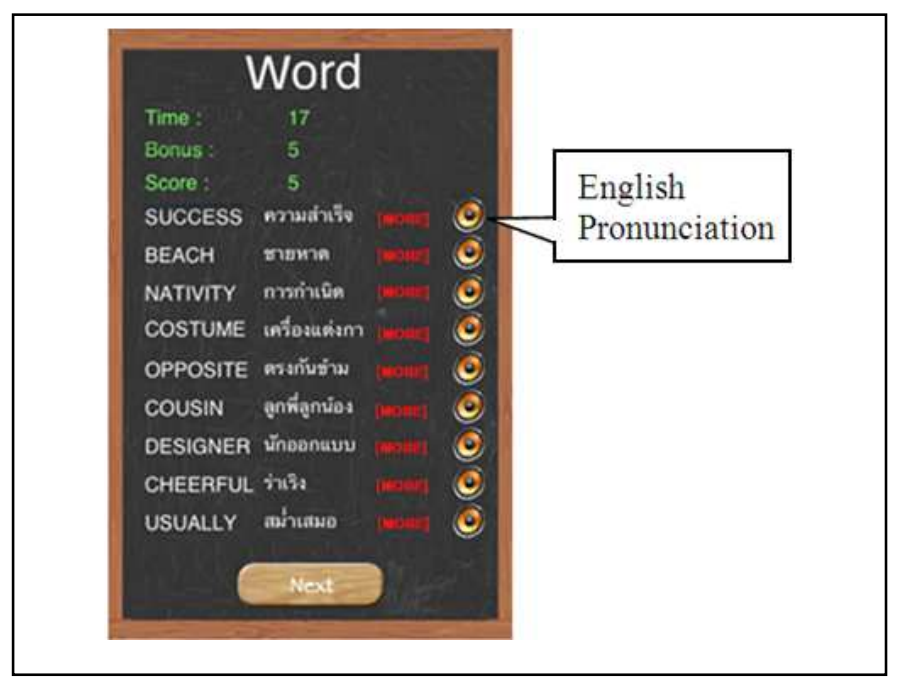

Fig. 7. The summarized score received at the end of each game including words and their pronunciation

\section{USABILITy EVALUATION PhASE}

As soon as our word search game on smart phones has been developed successfully, we begin to test the functionality of the game. In order to study the efficiency of our word search game, a set of 46 students is chosen without any specific criteria. They are divided into three small groups according to the test number shown in Table 2. The first group is equipped with smart phone and presented with some rules prior to the word search game on smart phones. For the second group, the students are not equipped with smart phones. But, they are introduced to use the web-based e-mail to obtain the English vocabulary. As it is similar to the work of Thornton and Houser [16], we sent many short messages to the students via e-mail with five English vocabulary words a day. It will be repeated when the twenty-five words had been sent. The student in the last group are not equipped with smart phones either. On the other hand, they receive small pieces of paper to play crossword game daily. However, there are some essential aspects that we should take into consideration at the time of sending vocabularies, for example, load of works that students have on hand to do during the certain period of times [21].

The students involved in our software evaluation process are introduced the word search game except the second group. Each group receives the same set of twenty-five words for one week. Though, English pretest of participants is made before separating students into three groups. The details of each group; group size and type of technology used; are briefly illustrated in Table 2. All groups have improved after two weeks of practicing. The percentage of improvement is calculated as below:

$$
\% \text { of improvemen } t=\frac{\text { post test }- \text { pre test }}{\text { postest }} \times 100
$$

From the experimental results, it turns out that students in the first group who have been equipped the word search game on smart phones has the highest improvement at $21.4 \%$. The other groups of students have lower improvement at $13.6 \%$ and $11.1 \%$ respectively. We can see that the word search on smart phones has improved the student scores twice as much as they received their vocabulary with crossword game on the papers. The last evaluation is the user satisfaction evaluation. This evaluation is made by participants of the first group. The result is shown in Table 3. It indicates that the respondents require an English dictionary in the game with the average score of 4.26. Additionally, the students prefer to manage their own word list with the average score of 4.25. The overall interface and system design are satisfactory; the average score of 4.04.

However, some feedbacks that were suggested by students to improve the word search game on smart phones are characters on screen, comprehension of the menus, presentation of the game and content, sequence of screens and game speed.

TABLE II. RESULTS OF USING WORD SEARCH GAME ON DIFFERENT TYPES OF TECHNOLOGY

\begin{tabular}{|c|c|c|c|c|c|c|c|}
\hline \multirow{3}{*}{$\begin{array}{c}\text { Group } \\
\text { No. }\end{array}$} & \multirow{3}{*}{$\begin{array}{c}\text { Smart } \\
\text { Phone } \\
\text { s }\end{array}$} & \multicolumn{2}{|c|}{$\begin{array}{c}\text { Types of } \\
\text { Technology }\end{array}$} & \multirow{3}{*}{$\begin{array}{l}\text { No. } \\
\text { of } \\
\text { stud } \\
\text { ents }\end{array}$} & \multirow{2}{*}{\multicolumn{2}{|c|}{$\begin{array}{l}\text { Test (25 } \\
\text { words) }\end{array}$}} & \multirow{3}{*}{$\begin{array}{c}\% \text { of } \\
\text { improve } \\
\text { ment }\end{array}$} \\
\hline & & \multirow{2}{*}{$\begin{array}{c}\text { Word } \\
\text { Search } \\
\text { game }\end{array}$} & \multirow{2}{*}{$\begin{array}{c}\text { e- } \\
\text { mail }\end{array}$} & & & & \\
\hline & & & & & $\begin{array}{l}\text { Pre } \\
\text { test }\end{array}$ & $\begin{array}{l}\text { Post } \\
\text { test }\end{array}$ & \\
\hline 1 & Yes & Yes & No & 16 & 15.4 & 18.7 & 21.4 \\
\hline 2 & No & No & Yes & 15 & 16.2 & 18.4 & 13.6 \\
\hline 3 & No & $\begin{array}{c}\text { Yes } \\
\text { (paper) }\end{array}$ & No & 15 & 14.9 & 16.9 & 11.1 \\
\hline
\end{tabular}


TABLE III. RESULTS OF EVALUATION OF THE EFFECTIVENESS OF THE SYSTEM (GROUP NO. 1 WITH 16 STUDENTS)

\begin{tabular}{|c|c|c|c|}
\hline No & Question & $\begin{array}{l}\text { Avg. } \\
\text { Score }\end{array}$ & SD \\
\hline \multicolumn{4}{|c|}{ Graphical interface design } \\
\hline 1. & Are Screen layouts helpful? & 4.15 & 1.52 \\
\hline 2. & $\begin{array}{l}\text { Arrange of information on } \\
\text { screen }\end{array}$ & 4.05 & 1.32 \\
\hline 3. & $\begin{array}{l}\text { Presentation of game and } \\
\text { contents }\end{array}$ & 3.80 & 1.12 \\
\hline 4. & Comprehension of menus & 3.37 & 1.34 \\
\hline 5. & Character on screen & 3.51 & 1.27 \\
\hline 6. & Image of buttons and icons & 3.90 & 1.19 \\
\hline 7. & Sequence of screens & 3.90 & 1.34 \\
\hline 8. & $\begin{array}{l}\text { The size of the buttons and icons } \\
\text { are appropriate. }\end{array}$ & 3.95 & 1.23 \\
\hline \multicolumn{2}{|r|}{ Average } & 3.83 & 1.29 \\
\hline \multicolumn{4}{|c|}{ System design } \\
\hline 9. & $\begin{array}{l}\text { Is this game suit to smart } \\
\text { phones? }\end{array}$ & 4.05 & 0.87 \\
\hline 10. & $\begin{array}{l}\text { Is the word search game on } \\
\text { smart phones facilitating you to } \\
\text { recognize the English } \\
\text { vocabulary words? }\end{array}$ & 4.08 & 1.31 \\
\hline 11. & $\begin{array}{l}\text { Did you feel the system under } \\
\text { control? }\end{array}$ & 4.05 & 0.67 \\
\hline 12. & $\begin{array}{l}\text { Variety of vocabulary words } \\
\text { provided in the game }\end{array}$ & 4.05 & 1.28 \\
\hline 13. & $\begin{array}{l}\text { How easy of making own } \\
\text { vocabulary lists? }\end{array}$ & 3.91 & 1.33 \\
\hline 14. & $\begin{array}{l}\text { How good is to create your word } \\
\text { list in this word search game? }\end{array}$ & $4.25^{*}$ & 1.48 \\
\hline 15. & $\begin{array}{l}\text { Is dictionary provided useful in } \\
\text { play the word search game? }\end{array}$ & $4.26^{*}$ & 0.97 \\
\hline 16. & $\begin{array}{l}\text { Is pronunciation provided in the } \\
\text { game suitable? }\end{array}$ & 4.04 & 1.12 \\
\hline 17. & $\begin{array}{l}\text { Is pronunciation provided in the } \\
\text { game facilitating you to learn } \\
\text { English? }\end{array}$ & 4.01 & 1.09 \\
\hline 18. & Game speed. & 3.98 & 1.13 \\
\hline 19. & $\begin{array}{l}\text { The overall design of the game } \\
\text { is appropriate. }\end{array}$ & 3.82 & 1.14 \\
\hline \multicolumn{2}{|r|}{ Average } & 4.04 & 1.12 \\
\hline
\end{tabular}

\section{CONCLUSION AND Discussions}

To the development of the word search game on smart phones, we conduct a survey to explore the needs of users. The study collects the data from 46 Thai students at Bangkok University, Thailand. An evaluation was carried out to the students to get feedback on the effectiveness and software design. We found that most Thai students positively preferred to play the word search game on smart phones if they can manage their own vocabulary words. In this paper, we try different techniques to compare with our word search game. Based on table 2, the result does not indicate that either word search on paper or e-mail attached with crossword vocabulary had less attraction to Thai students, but students participating in using our game got the best improvement. In addition, two special features that students preferred to have within the word search game on smart phones, while they are playing, are an English dictionary and its English pronunciation. In the future, the feedbacks should be also applied to improve the final game.

\section{ACKNOWLEDGMENT}

The authors would like to acknowledge the cooperation of students at Bangkok University participated in our research and voluntarily responded to questionnaires. Thanks also goes to Mr. Apiwat Nokted and Mr. Takrit Limwiras, who voluntarily developed the final version of the word search game on Iphones.

\section{REFERENCES}

[1] M. J. Mayo, "Games for Science and Engineering education communications of the ACM 50," 7, 2007, pp. 30-35.

[2] J. H. Valk, A. T. Rashid and L. Elder, "Using mobile phones to improve educational outcomes: An analysis of evidence from Asia," International Review of Research in Open and Distance Learning, Volume 11, Number, 2010.

[3] A.I. Wang and B. Wu, "An application of game development framework in higher education," International Journal of Computer Games Technology, Special Issue on Game Technology for Training and Education, Volume 2009.

[4] K. Salen and E. Zimmerman, "Rules of Play-Game Design Fundamentals," MIT Press, Cambridge, Mass, 2003.

[5] S. Franklin, M. Peat, and A.Lewis, , "Non-traditional interventions to stimulate discussion: The use of games and puzzles," Journal of Biological Education, vol.37(2), 2003, pp.76-82.

[6] W. R. Lee, "Language teaching games and contests," Oxford: Oxford University Press, 1979.

[7] E. Clua, B. Feijó, J. Schwartz, M. Graças, K. Perlin, R. Tori and T. Barnes, "Games and interactivity in Computer Science Education," Panel at SIGGRAPH, Boston, MA, 2006.

[8] F. Fotouhi-Ghazvini, D. Robison, R. A. Earnshaw and P. S. Excell, "The MOBO City: A Mobile Game Package for Technical Language Learning," International Journal of Mobile Technologies, Vol. 3, Issue 2, April 2009.

[9] H. C. Hung and S.C. Young, "Constructing the game-based learning environment on handheld devices to facilitate English vocabulary building," 7th IEEE International Conference on Advanced Learning Technologies ,ICALT, 2007, pp. 348-350.

[10] R. Rosas, M. Nussbaum, P. Cumsille, V. Marianov, M. Correa, P. Flores, V. Grau, F. Lagos, X. Lopez, V. Lopez, P. Rodriguez, and M. Salinas, "Beyond Nintendo: design and assessment of educational video games for first and second grade students," Computers \& Education, 40(1): 71-94, 2003.

[11] A. I. Wang, "An extensive evaluation of using a game project in a software architecture course," Transaction on Computing Education (ACM), 2009.

[12] G. M. Chinnery, "Emerging technologies going to the MALL: Mobile assisted language learning," Language Learning and Technology, January, 2006, Volume 10, Number 1 pp. 9-16.

[13] D. McConotha, M. Praul, and M.J. Lynch, "Mobile learning in higher education: An empirical assessment of a new educational tool," The Turkish Online Journal of Educational Technology, 7(3), 2008.

[14] M. Saran, K. Cagiltay, and G. Seferoglu, "Use of mobile phones in language learning: developing effective instructional materials," 5th International Conference on Wireless, Mobile and Ubiquitous Technologies in Education-WMUTE2008, 2008, pp.39-43. 
[15] S.H. Kim , C. Mims, and K.P. Holmes, "An introduction to current trends and benefits of mobile wireless technology use in higher education," AACE Journal, 14(1), 2006, pp. 77-100.

[16] P. Thornton, and C. Houser, "Using mobile phones in English education in Japan," Journal of Computer Assisted Learning, 21, 2005, pp. 217 228.

[17] M. Warschauer and D. Healey, "Computers and language learning: An overview," Language Teaching, 31, 1998, pp. 57-71.

[18] H. R. Hartson and D. Hix, "Toward empirically derived methodologies and tools for HCI development," International Journal of Man Machine Studies 31, 1998, pp. 477-494.

[19] A. Moreno-Muñoz, A. Plaza-Alonso, C. de-Castro-Lozano, and S. Dormido-Bencomo, "Hypermedia design methodology in World Wide Web applications," International Journal of Human-Computer Interaction, 14(2), 2002, pp. 251-270.

[20] M. Oğuz Kutlu, "Developing a scale on the usage of learner control strategy," Academic Journals, Educational Research and Reviews Vol. 7(10), 2012, pp. 244-250.

[21] I. Tosuncuoglu, "Usage of mother tongue in learning English," Academic Journals, Educational Research and Reviews Vol. 7(15), 2012, pp. 333-337.

\section{Creative Commons Attribution License 4.0 (Attribution 4.0 International, CC BY 4.0)}

This article is published under the terms of the Creative Commons Attribution License 4.0

https://creativecommons.org/licenses/by/4.0/deed.en_US 